Article

\title{
Groundwater Resources from Eastern Romania under Human and Climatic Pressure
}

\author{
Ionuț Minea ${ }^{1, *(\mathbb{D}}$, Marina Iosub $2 \mathbb{D}$ and Daniel Boicu ${ }^{1}$ \\ 1 Department of Geography, Faculty of Geography and Geology, Alexandru Ioan Cuza University of Iasi, \\ 700505 Iasi, Romania; boicu.d.daniel@gmail.com \\ 2 Integrated Center of Environmental Science Studies in the North Eastern Region-CERNESIM, \\ Alexandru Ioan Cuza University of Iasi, 700505 Iasi, Romania; iosub.marina@gmail.com \\ * Correspondence: ionutminea1979@yahoo.com; Tel.: +40-741-331-556
}

Received: 13 November 2020; Accepted: 7 December 2020; Published: 10 December 2020

check for updates

\begin{abstract}
Groundwater resources from a region may be subject to complex human and climatic pressure. The present study tries to analyze the human and climatic pressure on the groundwater resources from the eastern part of Romania, between 1983 and 2017, for seven groundwater bodies. Two parameters, the groundwater exploitation index (GWEI) and the Standardized Groundwater Index (SGI) for identifying hydrogeological droughts, were used to assess human and climatic pressure. The high values of GWEI show a significant increase in human pressure on water resources in recent decades, in lower and more populated areas, from the south and north part of de region, amid increasing investment in agriculture. In the case of climate pressure, the SGI values show significant values for the years 1983, 2000, 2007, and 2012. However, the overlap of hydrogeological droughts with an increase in human pressure can have a significant impact on the groundwater resources from this region, with negative effects in the mid and long term, under the growing effects of the regional climate changes.
\end{abstract}

Keywords: groundwater level; groundwater exploitation index; standardized groundwater index; Eastern Romania

\section{Introduction}

For our current society, the groundwater reserves represent one of the most important resources. The negative effects of the excessive, non-sustainable exploitation of the groundwater resources can be seen all around the world, with a more sustained prevalence in the third-world or developing countries. One of the most important causes behind the pressure exerted by excessive exploitation lies in the fact that the global population has quadrupled in the last century and it will continue to do so [1]. To make matters even more complicated, this population increase is also accompanied by a growing demand for food, which in turn, yields a direct effect through the needed increase in cultivated surfaces and the corresponding irrigation resources [2]. These requirements, coupled with the rapid development of the urban areas and the economic growth, lead to the overexploitation of both the surface and groundwater resources. It is estimated that approximately $35 \%$ of the world's population is affected by water stress, and this phenomenon's distribution is seen in areas such as Sahel, Southern Africa, Central America, Australia, India, Pakistan, and North-East China [1-5]. It is estimated that over $50 \%$ of the drinking water is being procured from underground sources and that around half of the large cities depend on it [3]. In Europe, the pressure on the groundwater resources is not that significant and it was concluded that approximately $18 \%$ of its population is subjected to water stress and that the most affected areas are found in the Mediterranean basin [6]. The general consensus for choosing groundwater resources as a water supply is based on the assumption that it experiences a 
slower response time to the seasonal and multi-annual climate changes. The areas which are suffering most from water scarcity are those that rely on groundwater as the main supply source. Although the areas that have large aquifers can use those as an extra water resource, often times the aquifers also end up being overexploited or even completely drained because the groundwater extraction exceeds the recharge capacity of the aquifers, both spatially and temporally. Such contexts can lead to decreases in the phreatic level, increases in the extraction costs, decreases in the natural water flow, soil alteration, as well as decreases in the water quality [2-5].

The pressure on groundwater was first observed back in the 1980s, when the scientific community started advancing concepts such as water scarcity and stress. The issues that are directly linked to the availability of drinking water are addressed in a multi-dimensional manner and this can be seen in the multitude of indices and criteria used in its assessment. The common practice involves a series of indices that are meant to identify climate anomalies and the time delay in the groundwater's response time [3]. Consequently, determining the exact time when, as a result of a drought, the groundwater resources begin to decrease, is of utmost importance in steadily decreasing the consumption and therefore avoiding entering a period of stress. Such indices are most of the time correlated with indices that can assess the economic and human stress that is induced by the decrease in the water resources. Such indices, which have been in use for more than 30 years, are the Falkenmark Indicator, Social Resources Water Stress Index, Critically ratio, Physical and Economic Water Scarcity Index, and the Relative Water Use Index [3,7-9]. The main direction in the use of such indicators is to try and identify the hierarchical importance of the society, its economy, as well as corresponding technology in the occurrence of the water stress and its perception in the ranks of the population: Physical or economic. This can be used further-on for identifying the water deficit that can be directly correlated to the available, sustainable water resources.

The strategic significance and the level of socio-economic security require special attention to the management of groundwater resources, especially since they constitute the main reservoir of fresh water at the level of local communities in the eastern part of Romania. Human pressure, doubled by the current and future climate changes, determines substantial changes of the groundwater-climate binom $[10,11]$. The growing variability between the hydric and atmospheric system, which is reflected in the moisture content of the soil cover, and the relationship between the surface and groundwater represents the most important change that may stress a very used resource [12]. The degree of vulnerability of the groundwater resources to the effects of climate change was highlighted by Dragoni and Sukhija [13] and IPCC [14,15].

In the last decades, studies were performed on the relation between climate change and groundwater. Based on punctual measurements, a number of statistical analysis and assessments were accomplished [16]. Moreover, the studies address the arid or semi-arid areas or those regions where the human impact against water resources is powerful [17]. The reaction of the groundwater resources to climatological drought and groundwater drought was studied by Krogulec (2019), Haas and Birk (2019), Kubicz and Bak (2019) [18-20].

The assessments that were made so far did not take into consideration parts of Eastern Europe, therefore, a thorough analysis regarding the vulnerability of groundwater resources to human and climate pressure in the eastern part of Romania (which mainly overlaps the Moldavian Plateau) was required. As the region is being affected by problems related to the way that people access the water supply, especially in rural communities. The vulnerability of groundwater resources from this area to anthropic impact was analyzed by Jora and Romanescu (2011) and Minea (2011) [21,22].

Geological conditions and the recent changes in land use from the last centuries transformed the wooded areas from Moldavian Plateau into intensively used agricultural areas, features that require a number of changes in the management of groundwater resources. These changes were analyzed in a number of recent papers, which highlighted the hydrological characteristics of the Moldavian Plateau and underground hydrostructures, the hydrogeologic regime or the relation between surface runoff and the groundwater level [23-25]. The studies regarding the assessment of climate change were 
made for the whole country [26,27] or were applied at a regional level [28,29]. The biggest differences were identified within the eastern and south-eastern parts of Romania, which sustained an increase in average air temperature and in the potential evapotranspiration rate at the end of the 20th century and the beginning of the 21st [30].

The constant need for development of the rural environments, the modernization of agricultural techniques through the emergence of new irrigated areas, the climate change that carries an intrinsic aridization trend of the Moldavian territory, all suggest a high pressure on the groundwater resources. This study aims to clearly highlight the fact that the pressure on drinkable water resources has seen an increase in the last years and that the droughts that have been extended over long periods of time in the last 20-30 years are all strongly affecting the groundwater resources. To this end, two calculus indices were used, the SGI, first proposed by Bloomfield and Marchant (2013), which shows the periods of sustained decrease in the groundwater resources, and as an assessment tool, the GWEI, which calculates the human pressure on the water resources [31]. With this methodology, the problematic areas can be identified and future plans can be applied for decreasing the water consumption or, even better, using it in a more sustainable way. This study can also be considered a starting point in the analysis of groundwater resources evolution in close connection with the efficient management plans of these resources for the mid and long term.

\section{Methods and Databases}

\subsection{Groundwater Resources Characteristics in Eastern Romania}

The Eastern region of Romania mainly overlaps the Moldavian region, with a great spatial representation of the hydrological resources' extent. These coincide with two main hydrographic basins: Prut and Siret rivers. The current study is focused on the analysis and assessment of the Eastern side of the area that overlaps with the Prut river basin. According to the European Framework 2000/60/EC [32], in the eastern part of Romania seven groundwater bodies (six national and one transboundary with Republic of Moldova) [33] were identified: ROPR01—upper flood plain of Prut river and its tributaries, ROPR02 - middle flood plain of Prut river and its tributaries, ROPR03-flood plain of Bârlad river and its tributaries, ROPR04-Covurlui Plain, ROPR05-Central Moldavian Plateau, ROPR06-Tecuci Plain, ROPR07-Moldavian Plain (Figure 1). All seven identified groundwater bodies belong to the porous type, being constituted in Quaternary and Sarmatian-Pontian deposits. Most groundwater bodies (ROPR01, ROPR02, ROPR03, ROPR04, ROPR06, and ROPR07) were delimited in the floodplains of the main rivers draining the region (Prut, Bârlad, and Siret), are developed in Quaternary alluvial, porous-permeable deposits. Located close to the ground surface, these groundwater bodies have a free piezometric level and are subject to human pressure both quantitatively and qualitatively. The evaluation matrix, which employs the qualitative and quantitative risk of each body, shows that five out of seven belong to the high or medium risk class [34]. The transboundary ROPR05 groundwater body (Central Moldavian Plateau), although it is under piezometric pressure, being confined in Sarmatian-Pontian deposits, it has lower economic importance. Furthermore, amid the occurrence of severe droughts episodes (like in 2000, 2007, 2011, 2012) [35] the lack of accurate information on the hydrogeological characteristics of the hydrostructures in which the groundwater is confined (the depth of the groundwater and geophysical characteristics of the geological structures) led to a number of administrative measures that had a low effectiveness rate in providing the required level of water supply for the population in extreme conditions. For example, following the severe drought of the summer of 2007, through Governmental Decision [36] (GD 822/2007) the execution of deep wells was proposed, in order to supplement the water demand in critical areas with high risk of drought situations in Vaslui County. Of the 35 wells executed, 16 have never been used so far, seven others had artesian water and cannot be connected to water supply systems, four were clogged, five were used for connecting the supply networks for the local water and three have not been completed (due to lack of funding or poor water quality). Given that the same situation happened in the entire 
region, we consider it worthwhile to emphasize the necessity of such an evaluation of the groundwater resources, especially since in this area, which covers more than $20,000 \mathrm{~m}^{2}, 50 \%$ of population lives in rural communities. The main water supply source is provided through the underground water, mainly from individual wells (only $25 \%$ of the rural population, in this region, is connected to a centralized water supply system). Groundwater resources are estimated at 251.4 million $\mathrm{m}^{3}$ (with a flow rate of $7.97 \mathrm{~m}^{3} / \mathrm{s}$ ) of which 34.7 million $\mathrm{m}^{3}\left(1.1 \mathrm{~m}^{3} / \mathrm{s}\right)$ come from groundwater sources, located near the surface and 216.7 million $\mathrm{m}^{3}\left(6.87 \mathrm{~m}^{3} / \mathrm{s}\right)$ from deep sources [37].

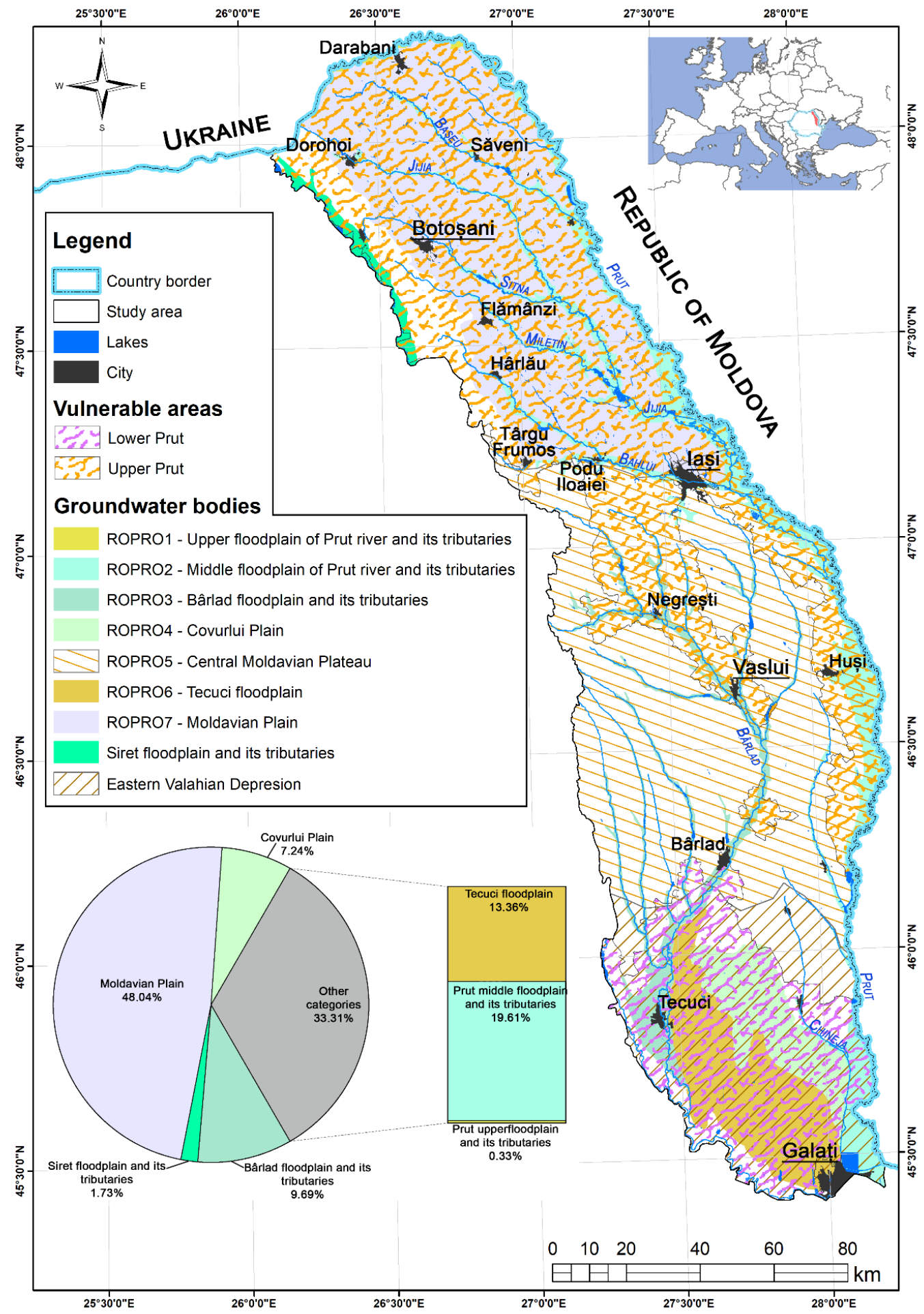

Figure 1. Groundwater bodies characteristics in Eastern Romania. 


\subsection{Methodology}

The assessment of human pressure on groundwater resources in the eastern part of Romania can be done through a multitude of methodologies. Two indices were selected, SGI and GWEI, the first for identifying the drought periods which are manifested at the groundwater level, and the second for determining the periods and the critical areas that are affected by water scarcity. These indices were used in order to establish a comparative analysis and in order to observe if any differences appear between the manifestation periods for the decrease of the groundwater levels. The methodology was applied to 42 hydrogeological wells (Figure 2), which are relatively evenly distributed in all groundwater bodies in the region. The period of the data sets analyzed is between 1983 and 2017.

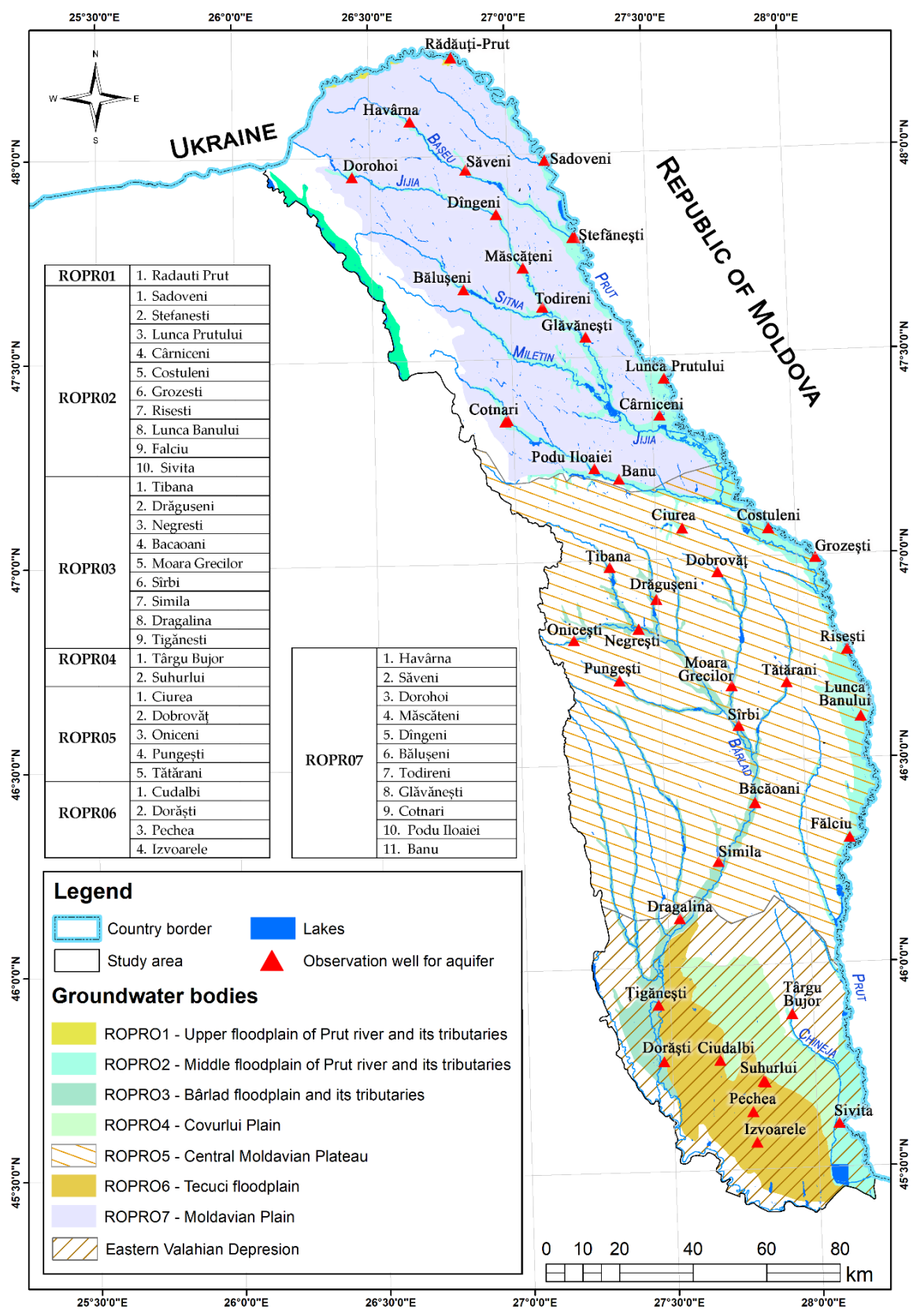

Figure 2. Hydrogeological wells analyzed in Eastern Romania. 


\subsubsection{Groundwater Exploitation Index (GWEI)}

The European Environment Agency developed an index for analyzing the human pressure on water resources: The Water Exploitation Index (WEI) [38]. This index can be scaled from the country to the river basin or sub-basin levels (WEI+), (EEA Water Exploitation Index Plus WEI+ for river basins districts, 2017). By extrapolating the way this index is analyzed, a Groundwater Exploitation Index (GWEI) can be calculated, which can be later applied to groundwater bodies in a given region. Taking into account the specificity of the natural conditions and the demographic and social evolution of the analyzed region, we consider that the groundwater exploitation index (GWEI) can be used successfully to that end. This index expresses the degree of pressure that human activities exert on natural groundwater resources in a given area (river basin, groundwater body, region, or national territory) in order to identify those areas prone to water deficit.

Mathematically, this index can be calculated using the following formula:

$$
G W E I=\frac{V i}{\sum V i, j / n} \times 100
$$

where: $V i$ represents the annual average of groundwater volume abstraction from specific groundwater body and $\Sigma V i, j$ the long-term annual volume of groundwater available for abstraction for each groundwater body and $n$ is the number of years analyzed. The average values of the extracted groundwater volumes are accessible in management plans created by the Romanian National Water Administration [37]. Methodological approaches for identifying such an index have been partially developed by [39]. As is the case of WEI +, if the GWEI values are below $10 \%$, then it is considered that water resources are not subject to human pressure. If the values are between $10 \%$ and $20 \%$, then it is considered that the water resources are included in reduced human pressure, and values of the exploitation index between $20 \%$ and $40 \%$ indicate the existence of high human pressure on the groundwater resources. Higher GWEI values of over $40 \%$ indicate the existence of extreme pressure on groundwater resources, with devastating impact in the mid and long term. The minimum period to be taken into account for the calculation of the long-term annual average of GWEI+ is 20 years. From the official data that were published in Romania, we can estimate the GWEI values for the eastern part of the country for the period 1990-2017. The global evaluations based on outdated information published in the period 1970-1990 cannot be considered as a database for correct scientific studies regarding the changes that took place within the groundwater level in the last decades, at the national or regional level.

\subsubsection{Standardized Groundwater Index (SGI)}

To evaluate climate pressure, the analysis was focused on the evolution of the periods of hydrogeological drought as an effect of the climate change observed in the region. The Standardized Groundwater Index (SGI) proposed by [31] has been used. This index is also based on the SPI methodology [40], but instead of using a gamma or log-normal distribution to transform the data series, it uses a non-parametric normal score transform. This is due to the fact that the SGI does not reflect an accumulation over a specific period because of the nature of the underlying groundwater level [41]. The non-parametric normalization assigns a value to the measured groundwater levels, based on their rank within a data set (from a specific month in a specific year). The normalization is made by applying the inverse normal cumulative distribution function to data series. The values obtained occur in the $1 / 2 n$ to $1 / 1-2 n$ interval and the SGI distribution passes the Kolmogorov-Smirnov test for normality. After obtaining the SGI values for each month, the SGI values for seasons and years can be derived. The results can be classified according to the drought indices used for hydrological droughts, as follows: SGI values under -2 correspond to extreme drought, the SGI values between -2 and -1.5 correspond to severe drought, the SGI values between -1.5 and -1 correspond to moderate 
drought, values of SGI between -1 and 0 correspond to minor drought and SGI values over 0 show no drought.

\section{Results}

\subsection{Demographic Backgrounds}

The total population of this region of Romania represents approximately 2.2 million inhabitants, of which $50.5 \%$ live in urban areas. All cities have a centralized water supply system for the population but the percentage of the population linked to these systems varies from one city to another (Figure 3). In rural areas, only $35 \%$ of the communities have a centralized water supply system. The numerical growth of the population together with the economic activities associated with agriculture (fish farming, livestock and farming, on about one million ha) and industry (industrial equipment, textiles, clothing, glass and ceramics, metallurgy) gave birth to a growing demand for water, which needs to be accessed from different sources. To supplement this increasing demand, the water supply system was developed relying on the neighboring river basins (for example, the water supply from the Moldova river basin, which is located near the mountainous area, constituted the primary source to the largest city in the region, Iasi, and it was constructed in the early twentieth century, and rescaled in the middle of the 1960s or by taking important volumes of water from the main hydrographic network (the Siret and Prut rivers). Concurrently, deep wells were drilled to extract water from the ground for the various sectors of economic activities.

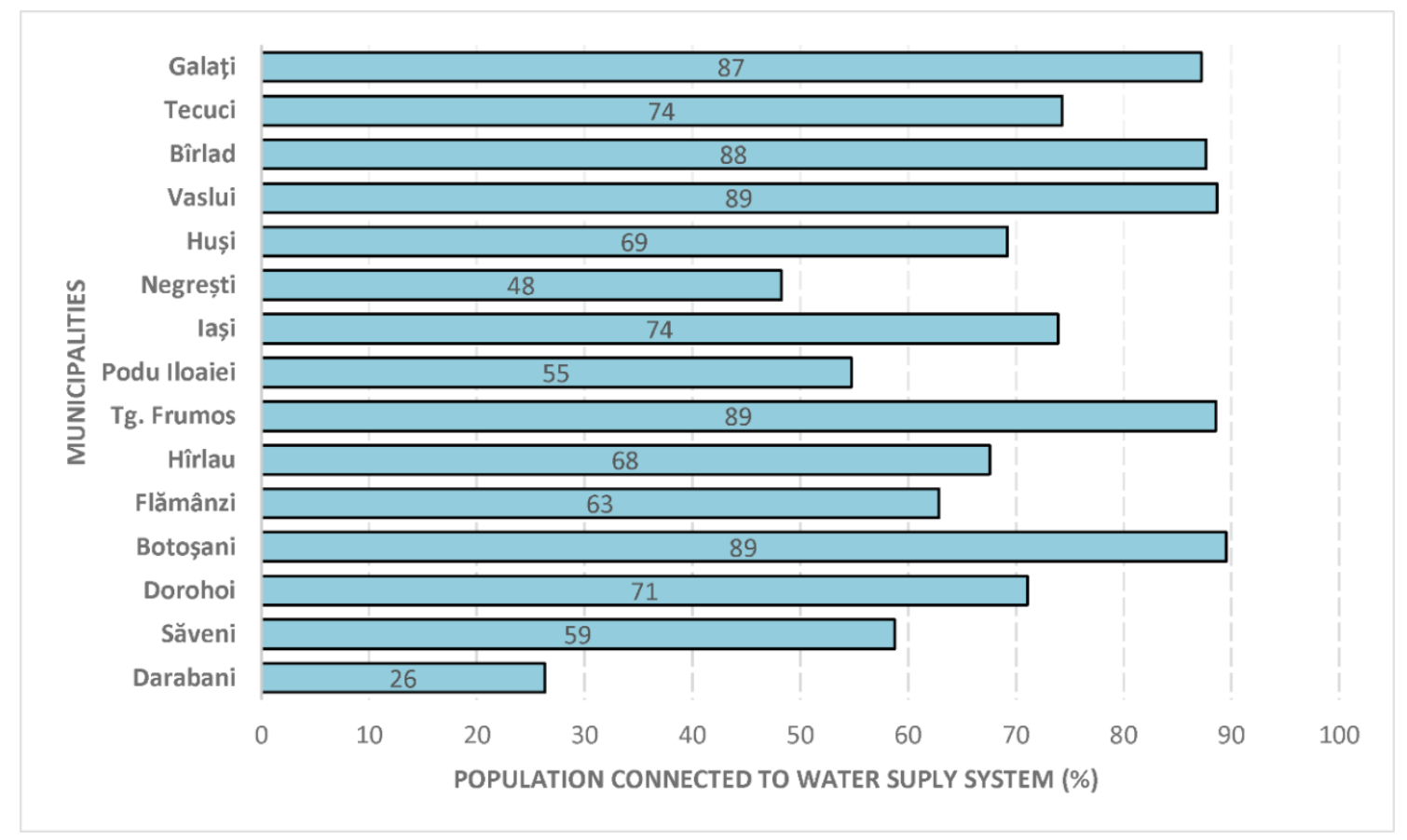

Figure 3. Population connected to water supply system (\%) in Eastern Romania.

The lowest water abstraction from underground is linked to the livestock, with average values of 1.6 million $\mathrm{m}^{3}$ per year and for industry, 13.7 million $\mathrm{m}^{3}$ per year (Figure 4). Agricultural activities, in all forms, irrigation or farming, lead the medium values in terms of water abstractions from the underground resources of this region, with average values of over 20.4 million $\mathrm{m}^{3}$ per year. The largest volumes of groundwater are extracted for water supply to the population, with an average of 71.7 million $\mathrm{m}^{3}$. The period with maximum values of groundwater extraction was between 1998 and 2002, with more than 105 million $\mathrm{m}^{3}$. In total, at the level of the entire region, water abstractions amount to 
an average of 107 million $\mathrm{m}^{3}$ per year, with annual variations depending on the natural conditions and the dynamics of various economic activities.

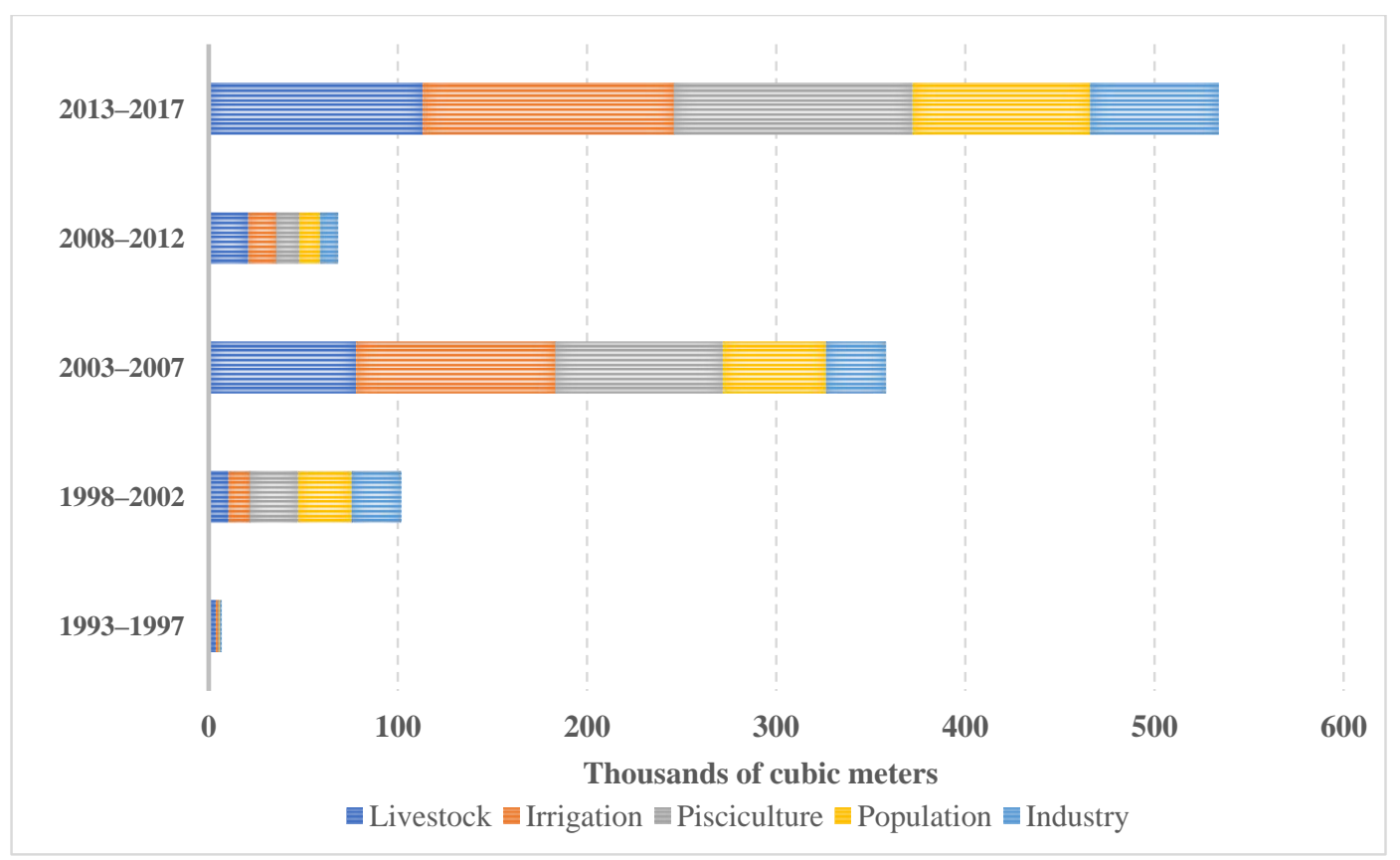

Figure 4. Groundwater abstractions by activity sectors in the period 1993-2017, in the eastern part of Romania.

\subsection{Groundwater Exploitation Index Evolution}

The evolution of the GWEI index for the eastern part of Romania was analyzed for each groundwater body. The spatial distribution of the hydrogeological wells allowed us to draw a number of conclusions regarding human pressure on groundwater resources. Thus, groundwater bodies that are located in low altitude areas, where land use is predominantly agricultural (in the south and north part of the region), exhibited GWEI values that had an increasing tendency in the last two decades (Figure 5).

Extraction of groundwater for various agricultural activities has led to increased human pressure on these water resources. Groundwater bodies located along the main rivers that are draining the region (ROPR03, ROPR04, ROPR06, and ROPR07) and located in more densely populated and agricultural areas have a negative evolution of the GWEI index, accentuated by the overexploitation of groundwater in dry periods. The increasing human pressure is manifested especially at the level of groundwater bodies ROPR04 and ROPR06, where the investments made by the inhabitants in the development of vegetable farming as a basic economic activity, have led to very high demand for water, often taken directly from underground through means of individual wells. The groundwater body ROPR05, with important water reserves at depths over $10 \mathrm{~m}$ and covering a less populated and more forested areas has no significant fluctuations of the GWEI index. The groundwater bodies placed along the Prut River also do not reflect significant human pressure in recent decades due to the irrigation systems that take water from surface resources (from Prut River and its tributaries and lakes) developed in recent decades. The temporal evolution of this indicator does not show a clear trend. It is observed that in recent decades, the frequency of GWEI classification for ROPR04, ROPR06, and ROPR07 in the value range between $0 \%$ and $10 \%, 10 \%$ and $20 \%$ and even $20 \%$ and $30 \%$ in one case, shows the increase of human pressure, even if reduced at the current level, on groundwater resources. 

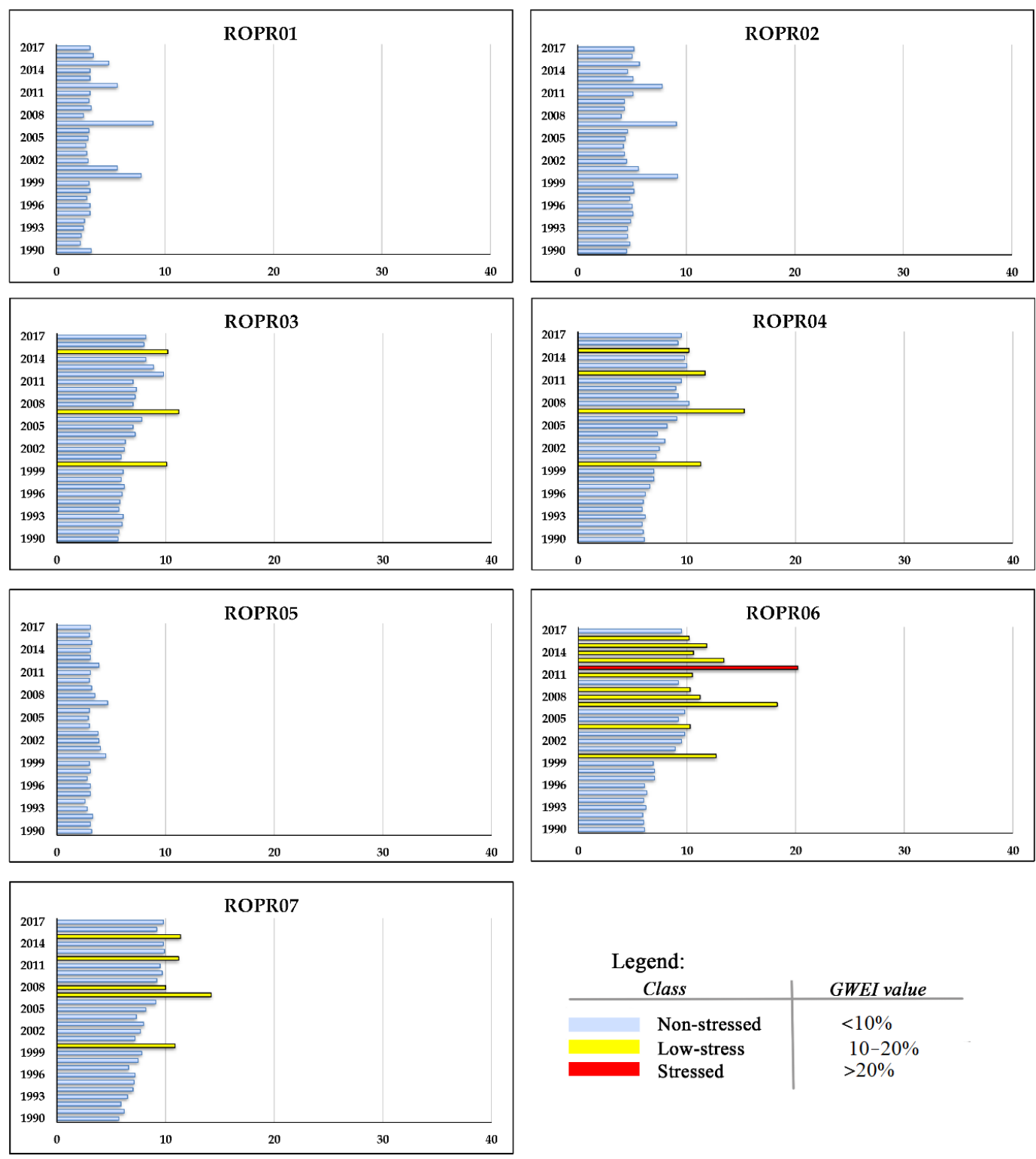

Figure 5. GWEI evolution in Eastern Romania between 1990 and 2017.

GWEI averages values for different decades do not indicate high human pressure on the groundwater reserves in the region (Figure 6). However, there are several years with higher values of GWEI $(2000,2007,2012)$ when four of the seven groundwater bodies analyzed indicate an increase of human pressure, and in 2012 at ROPR06 even reaching the level of significant human pressure. 


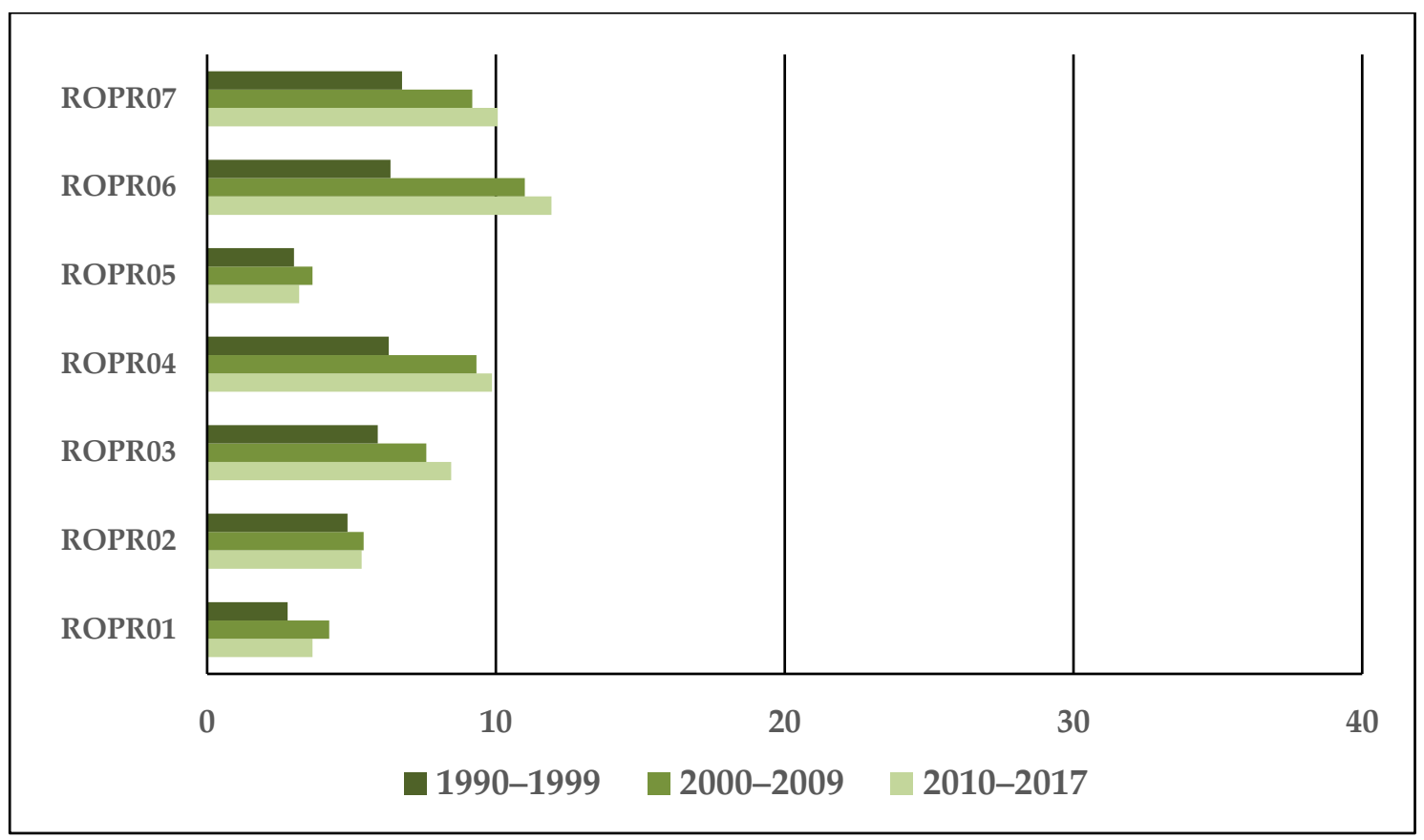

Figure 6. Decadal evolution of GWEI in groundwater bodies in Eastern Romania.

\subsection{Groundwater Drought Evolution}

For the groundwater drought analysis, the data from the hydrogeological wells included at the level of each groundwater body were aggregated and the results represent the evolution of this parameter for each groundwater body. The appearance of hydrogeological droughts is a final stage of a long process of manifestation determined by the lack of significant amounts of water coming from precipitation. Therefore, the results obtained can rarely be correlated with the evolution of hydro-climatic parameters at the surface. Given that the water supply is significantly reduced, the hydrogeological drought manifests itself at increasing depths, reducing the volumes of groundwater to values that are no longer economically important. The temporal evolution of the hydrogeological droughts was analyzed at the water body level, based on the data from the hydrogeological drillings included in the respective underground water body. Following the cumulative graphical representation of the SGI index values (Figure 7) for all hydrogeological wells in the region, for the period 1983-2017, a succession of three important hydrogeological drought periods is observed. The first period occurs at the beginning of the analyzed time interval, between 1983 and 1986, as an effect of a period of atmospheric and hydrological drought manifested in 1982 [42]. 


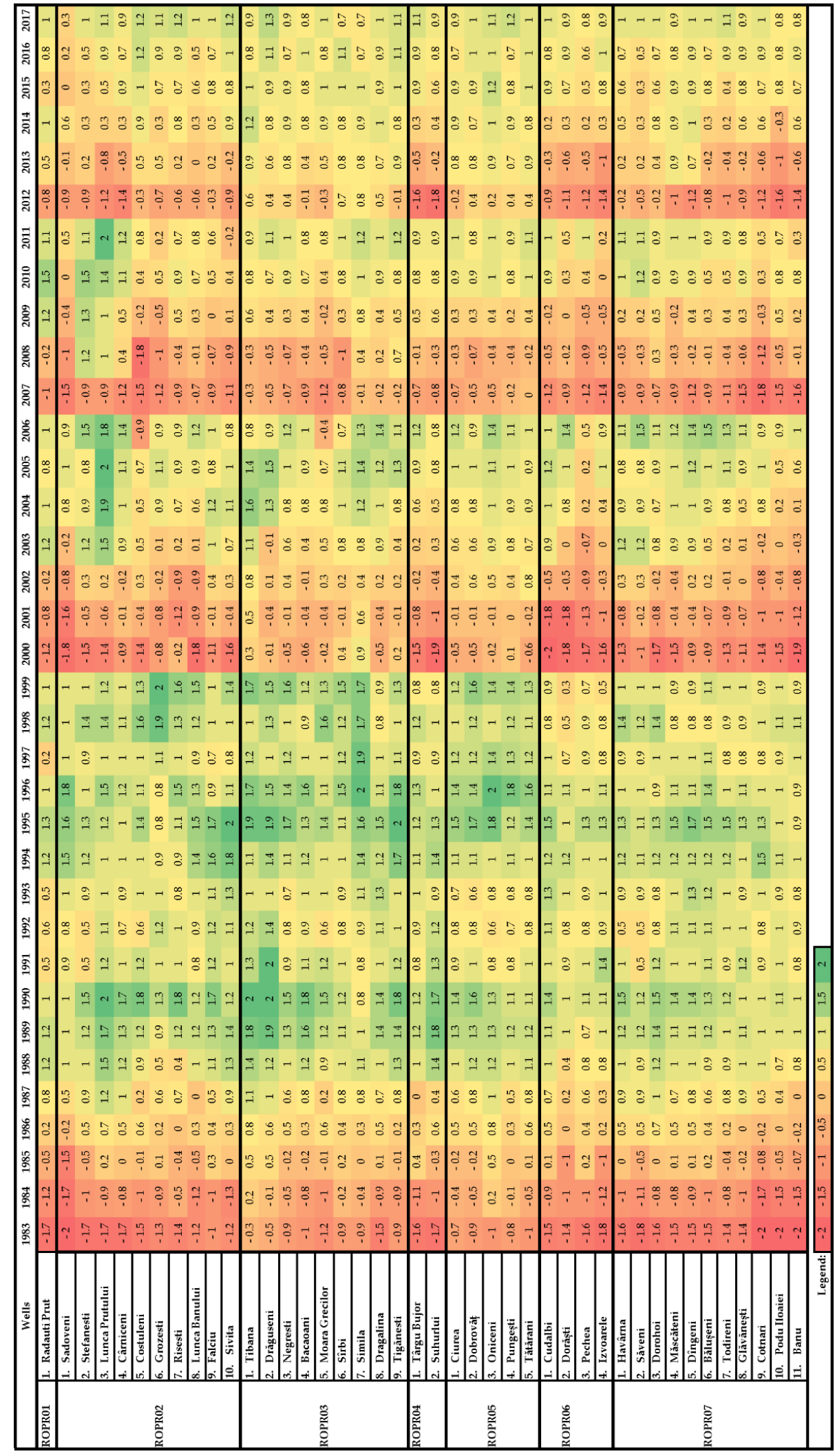

Figure 7. The Standardized Groundwater Index (SGI) values for hydrogeological wells from Eastern Romania.

The second period manifested itself in the early 2000s, with a succession of one to three years with SGI values of less than -1 in over $80 \%$ of the analyzed boreholes. The third period of hydrogeological 
drought occurs after 2007 and extends for one to two years to over $75 \%$ of wells. Later and at the level of 2012, a slight tendency of a hydrogeological drought can be observed, but without reaching the magnitude of the previous ones. At the body level, by aggregating the SGI values for all the included hydrogeological wells, it is observed that at 2two groundwater bodies, ROPR03 and ROPR05, no significant hydrogeological droughts were manifested. At four groundwater bodies, ROPR01, ROPR04, ROPR06, and ROPR07, even at the level of year 1983, the aggregated values of SGI show a significant hydrogeological drought (marked in red in Figure 8). Other significant hydrogeological droughts occurred in 2000 and 2012, for groundwater bodies ROPR04 and ROPR06, where SGI values decrease under -1.5 . The SGI values were between -1 and -1.5 for the groundwater bodies ROPR01, ROPR02, and ROPR07, in 2000, 2007, and 2012.
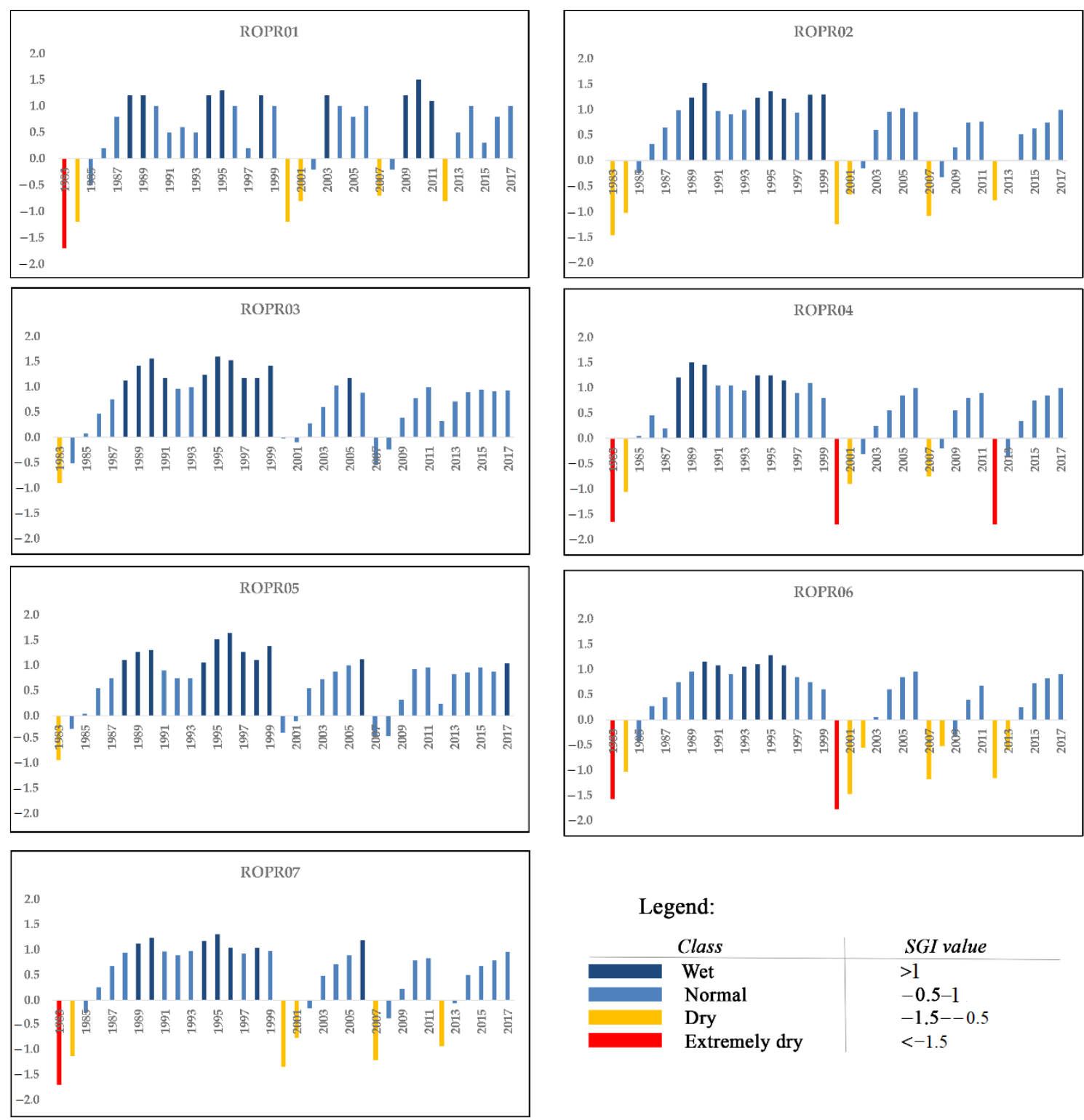

Figure 8. SGI values for groundwater bodies from Eastern Romania.

\section{Discussion}

The analysis of human and climate pressure on the groundwater resources in the eastern part of Romania is conditioned by the lack of relevant data, especially for the years of the communist period (before 1990). However, it has been observed that the human impact is quite significant in the case 
of certain groundwater bodies (ROPR04, ROPR06, ROPR07), and, correlated with the vulnerability of surface water resources in this region [43], can generate increasing human pressure in the mid and long term. The economic evolution of the area, with important investments in agriculture, along with the climate evolution generated by climate change, can put additional pressure on the existing groundwater resources. Research on the evolution of climate and hydrological parameters at the surface has shown trends of a slight increase in precipitation [30], hydro-climatic extremes [44], and hydrological balance [45]. On the other hand, the anomalies that appeared in the manifestations of the hydro-climatic extremes put additional pressure on the surface water resources [46]. Current trends in groundwater level evolution in the region are correlated with trends in the amount of rainfall, but manifested only up to a depth of 2-3 $\mathrm{m}$ in the underground, and largely tend to reach lower and lower levels compared with the land surface $[47,48]$. Therefore, the overlap of hydrogeological droughts with an increase in anthropogenic pressure can generate a significant impact on groundwater resources, with negative effects, especially in areas where there are no alternatives in identifying new water sources.

The comparative analysis of the two indices reveals the fact that in the Eastern region of Romania, the decrease of the groundwater resources occurs as a natural response to a precipitation deficit over a certain period of time. The fact that their frequency has increased in the last decade is caused most likely by climate change, which in this particular area, are manifested in the form of hydrological extremes, both in the positive and negative side of the spectrum. Since the study area is subject to a complete water deficiency in certain years, it is a good indicator of the fact that the decrease of the water resources is in fact caused by drought and less so by the extended anthropic impact. The key values for the two indicators, SGI and GWEI, can be isolated as the ones from the years with drought, and can be correlated to and used for assessing the impact of the human pressure under its various forms over the water resources. To that end, we can observe that the years which experience drought phenomena and which indicate a real deficit, 1983-1984, 2000-2001, 2007-2008, and 2012-2013, are found in both analyses to be with a particular water deficit. For the GWEI indicator and its corresponding analysis, there are no water stress periods, aside from the drought periods, and the difference is in the fact that in such periods, the stress increases even more, compared to the regions which have a regular lower groundwater exploitation rate.

\section{Conclusions}

The evaluation of groundwater resources in the eastern part of Romania, classified according to the appurtenance to different groundwater bodies, was performed in two directions of analysis: Human impact and pressure induced by the evolution of climatic elements, especially at hydrogeological droughts level. The human pressure analysis was performed based on the GWEI index, which highlighted a significant increase in anthropogenic impact in recent decades, based on significant growth in agricultural investments that generated an increase of groundwater volume extractions through individual wells for vegetable farming. This was observed especially after the year 2000, in the case of groundwater bodies located in lower altitude areas and with a higher population density (ROPR04, ROPR06, and ROPR07). Over this human pressure, overlapped periods of hydrogeological drought were evaluated by applying a synthetic index (SGI). The years with SGI values below -1 do overlap with those with GWEI values that show an increase in anthropogenic pressure, except for the year 2000, when a severe hydrogeological drought overlapped with a growing need for water that generated a very high pressure and a large impact on groundwater resources. The obtained results constitute the first phase of analysis of the vulnerability of these resources in front of the anthropic and climate pressure and can be a starting point in the evaluation of the dynamics of these resources in different scenarios of socio-economic and climate evolution of the region.

Author Contributions: Conceptualization, I.M. and M.I.; methodology, I.M.; software, M.I.; validation, I.M., M.I. and D.B.; formal analysis, I.M.; investigation, I.M.; resources, I.M.; data curation, I.M.; writing-original draft preparation, D.B.; writing — review and editing, I.M.; visualization, M.I.; supervision, I.M.; project administration, I.M.; funding acquisition, I.M. All authors have read and agreed to the published version of the manuscript. 
Funding: This work was supported by a grant of the Romanian Ministry of Education and Research CNCS-UEFISCDI, project number PN-III-P1-1.1-TE-2019-0286, within PNCDI III.

Acknowledgments: The authors are grateful for the hydrogeological data provided by the Prut Barlad Basin Branch of the Romanian National Water Administration.

Conflicts of Interest: The authors declare no conflict of interest.

\section{References}

1. Wada, Y. Modeling Groundwater Depletion at Regional and Global Scales: Present State and Future Prospects. Surv. Geophys. 2015, 37, 419-451. [CrossRef]

2. Changming, L.; Jingjie, Y.; Kendy, E. Groundwater Exploitation and Its Impact on the Environment in the North China Plain. Water Int. 2001, 26, 265-272. [CrossRef]

3. Lezzaik, K.; Milewski, A.; Mullen, J. The groundwater risk index: Development and application in the Middle East and North Africa region. Sci. Total Environ. 2018, 628, 1149-1164. [CrossRef] [PubMed]

4. Groundwater Foundation. Overuse and Depletion. Available online: https://www.groundwater.org/getinformed/groundwater/overuse.html (accessed on 10 November 2020).

5. Bartolino, J.R. Ground-Water Depletion Across the Nation. In USGS Fact-Sheet; US Department of the Interior, US Geological Survey: Reston, VA, USA, 2003; pp. 1-4.

6. European Environmental Agency. (WQ01c) Water Exploitation Index, Indicator Fact Sheet. Available online: https://www.eea.europa.eu/data-and-maps/indicators/water-exploitation-index/water-exploitationindex (accessed on 10 November 2020).

7. Falkenmark, M.; Lundqvist, J.; Widstrand, C. Macro-scale water scarcity requires micro-scale approaches. Nat. Resour. Forum 1989, 13, 258-267. [CrossRef]

8. Brown, A.; Matlock, M.D. A Review of Water Scarcity Indices and Methodologies; White Paper 106; The Sustainability Consortium: Fayetteville, AR, USA, 2011; p. 19.

9. Vorosmarty, C.J. Global Water Resources: Vulnerability from Climate Change and Population Growth. Science 2000, 289, 284-288. [CrossRef]

10. Taniguchi, M.; Holman, I.P. Groundwater Response to Changing Climate; International Associations of hydrogeologist-Selected Papers; CRC Press: Boca Raton, FL, USA, 2017; p. 246.

11. Kim, H.; Lim, C. Strategies to Assure the Sustainability of Groundwater Resources. Sustainabilty 2020, $12,9183$. [CrossRef]

12. Taylor, R.G.; Scanlon, B.; Döll, P.; Rodell, M.; Van Beek, R.; Wada, Y.; Longuevergne, L.; Leblanc, M.; Famiglietti, J.S.; Edmunds, M.; et al. Ground water and climate change. Nat. Clim. Chang. 2013, 3, 322-329. [CrossRef]

13. Dragoni, W.; Sukhija, B.S. Climate change and groundwater: A short review. Geol. Soc. Lond. Spéc. Publ. 2008, 288, 1-12. [CrossRef]

14. Alcamo, J.; Moreno, J.M.; Nováky, B.; Bindi, M.; Corobov, R.; Devoy, R.J.N.; Giannakopoulos, C.; Martin, E.; Olesen, J.E.; Shvidenko, A. Europe. In Climate Change 2007: Impacts, Adaptation and Vulnerability; Contribution of Working Group II to the Fourth Assessment Reportof the Intergovernmental Panel on Climate Change; Cambridge University Press: Cambridge, UK, 2007; pp. 541-580.

15. IPCC. Climate Change 2014: Synthesis Report; Contribution of Working Groups I, II and III to the Fifth Assessment Report of the Intergovernmental Panel on Climate Change; IPCC: Geneva, Switzerland, 2014.

16. Hiscock, K.; Sparkes, R.; Hodgson, A. Evaluation of Future Climate Changes Impacts on European Groundwater Resources in Climate Change Effects of Groundwater Resources: A Global Synthesis of Findings and Recommendations; CRC Press: Boca Raton, FL, USA, 2011.

17. Schwabe, K.A.; Connor, J.D. Drought Issues in Semi-arid and Arid Environments. Choices 2012, 27, 1-5.

18. Krogulec, E.; Zabłocki, S.; Zadrożna, D. Variability of Intrinsic Groundwater Vulnerability to Pollution in River Valley due to Groundwater Depth and Recharge Changes. Appl. Sci. 2019, 9, 1133. [CrossRef]

19. Haas, J.C.; Birk, S. Trends in Austrian groundwater-Climate or human impact? J. Hydrol. Reg. Stud. 2019, 22, 100597. [CrossRef]

20. Kubicz, J.; Bak, B. The Reaction of Groundwater to Several Months' Meteorological Drought in Poland. Pol. J. Environ. Stud. 2018, 28, 187-195. [CrossRef] 
21. Jora, I.; Romanescu, G. Groundwater in the hydrographical basin of the Vaslui river. Pap. Geogr. Semin. Dimitrie Cantemir 2011, 31, 21-28.

22. Minea, I. Streamflow-base flow ratio in a lowland area of North-Eastern Romania. Water Resour. 2017, 44, 579-585. [CrossRef]

23. Panaitescu, E. Groundwater and Depth Aquifer in the Barlad River Basin; Demiurg Publishing House: Iasi, Romania, 2007.

24. Radu, C.; Pandele, A.; Radescu, M. PROJECT CC-WATERS-Climate Change and Impacts on Water Supply. In Proceedings of the 10th International Multidisciplinary Scientific Geoconference, Sofia, Bulgaria, 20-26 June 2010; Volume II, pp. 259-264.

25. Minea, I.; Crăciun, I. Simulation models to evaluate the groundwater resources in Bahlui river basin. J. Environ. Prot. Ecol. 2012, 13, 1600-1607.

26. Busuioc, A.; Caian, M.; Cheval, S.; Bojariu, R.; Boroneant, C.; Baciu, M.; Dumitrescu, A. Variability and Climate Change in Romania; Pro Universitaria Press: Bucharest, Romania, 2010.

27. Birsan, M.; Zaharia, L.; Chendes, V.; Branescu, E. Seasonal trends in Romanian streamflow. Hydrol. Process. 2013, 28, 4496-4505. [CrossRef]

28. Croitoru, A.E.; Toma, F.M. Climatic Changes and Their Influence on Streamflow in Central Romanian Plain. In Proceedings of the 5th Atmospheric Science Symposium, Istanbul, Turkey, 27-29 April 2011; pp. 183-194.

29. Piticar, A.; Ristoiu, D. Analysis of air temperature evolution in northeastern Romania and evidence of warming trend. Carpathian J. Earth Environ. Sci. 2012, 7, 97-106.

30. Croitoru, A.-E.; Minea, I. The impact of climate changes on rivers discharge in Eastern Romania. Theor. Appl. Clim. 2014, 120, 563-573. [CrossRef]

31. Bloomfield, J.P.; Marchant, B.P. Analysis of groundwater drought building on the standardised precipitation index approach. Hydrol. Earth Syst. Sci. 2013, 17, 4769-4787. [CrossRef]

32. Quevauviller, P. Water Framework Directive. J. Soils Sediments 2007, 7, 111-116. [CrossRef]

33. Bretotean, M.; Macalet, R.; Tenu, A.; Tomescu, G.; Munteanu, M.T.; Radu, E.; Radu, C.; Dragusin, D. Romania's cross-border underground water bodies. Hidrogeologia 2006, 7, 16-21.

34. Minea, I. Bahlui Drainage Basins—Hydrological Study; Alexandru Ioan Cuza University Press: Iași, Romania, 2012.

35. Sfîcă, L.; Croitoru, A.-E.; Iordache, I.; Ciupertea, A.-F. Synoptic Conditions Generating Heat Waves and Warm Spells in Romania. Atmosphere 2017, 8, 50. [CrossRef]

36. Governement Decision no. 822 of 25 July 2007 on the Allocation of an Amount from the Intervention Fund at the Disposal of the Government, Provided in the State Budget for 2007, for the Execution of Drillings in Order to Ensure Additional Water Sources, in Order to Reduce the Effects of Prolonged Drought. Available online: legislatie.just.ro/Public/DetaliiDocument/84002 (accessed on 12 November 2020).

37. Romanian Water National Administration. River Basin Management Plan for Hydrographic Basin Prut-Barlad 2016-2021. 2018. Available online: http://www.rowater.ro/daprut/Plan\%20management\%20bazinal/Forms/ Allitems.aspx (accessed on 5 November 2020).

38. European Environmental Agency. Water Exploitation Index Plus WEI+ for River Basins Districts. 2017. Available online: http://www.eea.europa.eu/data-and-maps/explore-interactive-maps/water-exploitationindex-for-river-1 (accessed on 10 November 2020).

39. Wang, Z.Q.; Wu, Q. Sustainability of Groundwater Resources and its Indicators. In Proceedings of the Symposium S3 Held During the Seventh IAHS Scientific Assembly, Foz do Iguaçu, Brazil, 3-9 April 2005.

40. McKee, T.B.; Doesken, N.J.; Kleist, J. The relationship of drought frequency and duration to time scale. In Proceedings of the Eighth Conference on Applied Climatology, Anaheim, CA, USA, 17-22 January 1993.

41. Bloomfield, J.P.; Marchant, B.P.; McKenzie, A.A. Changes in groundwater drought associated with anthropogenic warming. Hydrol. Earth Syst. Sci. 2019, 23, 1393-1408. [CrossRef]

42. Sandu, I.; Pescaru, V.I.; Poiana, I. Climate of Romania; Romanian Academy Press: Bucharest, Romania, 2008.

43. Minea, I. The Vulnerability of Water Resources from Eastern Romania to Anthropic Impact and Climate Change. In Water Resources Management in Romania; Springer: Cham, Switzerland, 2020; pp. 229-250.

44. Croitoru, A.E.; Piticar, A.; Sfîcă, L.; Harpa, G.V.; Roșca, C.F.; Tudose, T.; Horvath, C.; Minea, I.; Ciupertea, F.A.; Scripcă, A.B. Extreme Temperature and Precipitation Events in Romania; Romanian Academy Press: Bucharest, Romania, 2018; p. 342. 
45. Prăvălie, R.; Piticar, A.; Roșca, B.; Sfîcă, L.; Bandoc, G.; Tiscovschi, A.; Patriche, C. Spatio-temporal changes of the climatic water balance in Romania as a response to precipitation and reference evapotranspiration trends during 1961-2013. Catena 2019, 172, 295-312. [CrossRef]

46. Minea, I.; Chelariu, O.E. Anomalies and trends of high river flow under temperate climatic conditions in north-eastern Romania. J. Water Clim. Chang. 2020. [CrossRef]

47. Minea, I.; Croitoru, A.-E. Groundwater Response to Changes in Precipitations in North-Eastern Romania. Environ. Eng. Manag. J. 2017, 16, 643-651. [CrossRef]

48. Minea, I.; Boicu, D.; Chelariu, O.E. Detection of Groundwater Levels Trends Using Innovative Trend Analysis Method in Temperate Climatic Conditions. Water 2020, 12, 2129. [CrossRef]

Publisher's Note: MDPI stays neutral with regard to jurisdictional claims in published maps and institutional affiliations.

(C) 2020 by the authors. Licensee MDPI, Basel, Switzerland. This article is an open access article distributed under the terms and conditions of the Creative Commons Attribution (CC BY) license (http://creativecommons.org/licenses/by/4.0/). 